\author{
Aspen Dynamics ${ }^{\mathrm{TM}}$ 와 $\mathrm{ACM}$ 을 이용한 용융탄산염 연료전지 시스템의 \\ 모사 및 제어 \\ 전경연 · 곽하연 · 경지현 · 이태원* · 문길호* · 이기풍* · 류이림* · 양대륙 \\ 고려대학교 화공생명공학과 \\ 136-713 서울특별시 성북구 안암동 5 가 \\ *두산중공업 기술연구원 연료전지개발센터 \\ 305-811 대전광역시 유성구 전민동 463-1 \\ (2010년 11월 18일 접수, 2010년 12월 24일 채택)
}

\title{
Simulation and Control of the Molten Carbonate System using Aspen Dynamics $^{\mathrm{TM}}$ and ACM
}

\author{
Kyoung Yein Jeon, Ha Yeon Kwak, Ji Hyun Kyung, Ahrim Yoo*, Tae Won Lee*, Gi Pung Lee*, \\ Kil ho Moon* and Dae Ryook Yang ${ }^{\dagger}$
}

Department of Chemical Engineering, Korea University, 5-ga, Anam-dong, Seongbuk-gu, Seoul 136-713, Korea *Fuel Cell System Development, Technology Institute, Doosan Heavy Industries Co., 463-1, Jeonmin-dong, Yuseong-gu, Daejeon 305-811, Korea (Received 18 November 2010; accepted 24 December 2010)

\begin{abstract}
요 약
최근 대체에너지에 대한 관심이 높아짐에 따라 수소에너지를 기반으로 하는 차세대 발전 장치인 연료전지 관련 기 술 개발이 활발하게 이루어지고 있다. 특히, 고온 연료전지의 대표적인 형태인 용융 탄산염 연료전지(MCFC: Molten Carbonate Fuel Cell, 이하 MCFC)는 전력사업용으로의 높은 가능성을 인정받아 화석연료를 대체할 발전방식으로 평 가 받고 있다. 본 연구에서는 Aspen Custom Modeler( $\left.\mathrm{ACM}^{\mathrm{TM}}\right)$ 에서 평형반응식을 이용하여 스택 모델을 구성한 후, Aspen Plus ${ }^{\mathrm{TM}}$ 에서 $\mathrm{BOP}$ (Balance of Plant) 시스템과 스택을 연결하여 전체 MCFC 발전 시스템의 정상상태를 모사하 였다. 모델의 유효성을 입증하기 위해서 전류밀도, 연료이용률, $\mathrm{S} / \mathrm{C}$ ratio, 재순환 흐름 비와 같은 주요 조업변수에 따른 셀 전압, 전력, 효율 등 시스템의 성능을 분석하였다. 그리고 Aspen Dynamics ${ }^{\mathrm{TM}}$ 에서 PID제어 방식을 적용하여 제어 루프를 구성하였고 부하변화, 설정점 변화, 재순환 흐름비 변화에 따른 각각의 사례연구를 통하여 전체 시스템의 성능 변화를 예측하였다. 그 결과 연료이용률과 전류밀도의 변화에 따른 전체 시스템의 최대 발전 효율 및 출력전압을 위한 운전조건을 제안하였다.
\end{abstract}

\begin{abstract}
Recentincreasing awareness of the environmental damage caused by the $\mathrm{CO}_{2}$ emission of fossil fuelsstimulated the interest in alternative and renewable sources of energy. Fuel cell is a representative example of hydrogen energy utilization. In this study, Molten Carbonate Fuel Cell system is simulated by using Aspen ${ }^{\mathrm{TM}}$. Stack model is consisted of equilibrium reaction equations using $\mathrm{ACM}^{\mathrm{TM}}$ (Aspen Custom Modeler). Balance of process of fuel cell system is developed in Aspen Plus ${ }^{\mathrm{TM}}$ and simulated at steady-state. Analysis of performance of the system is carried out by using sensitivity analysis tool with main operating parameters such as current density, S/C ratio, and fuel utilization and recycle ratio.In Aspen Dynamics ${ }^{\mathrm{TM}}$, dynamics of MCFC system is simulated with PID control loops. From the simulation, we proposed operation range which generated maximum power and efficiency in MCFC power plant.
\end{abstract}

Key words: MCFC, Modeling, Simulation, PID

\section{1. 서 론}

최근 환경파괴 및 화석연료 고갈에 따른 대안으로 청정에너지에 대한 관심이 고조됨에 따라 미래에너지 매체로 우수한 특성을 지니

\footnotetext{
${ }^{\dagger}$ To whom correspondence should be addressed.

E-mail: drying@prosys.korea.ac.kr

†이 논문은 고려대학교 홍석인 교수님의 정년을 기념하여 투고되었습니다.
}

는 수소에너지 기술개발에 대한 필요성이 증대되고 있다. 이에 따라 수소에너지를 기반으로 하는 차세대 발전장치인 연료전지가 각광을 받고 있으며 연료전지 관련 기술개발도 활발하게 이루어지고 있다. 연료전지는 연료가 가지고 있는 화학에너지를 전기화학 반응에 의 해 직접 전기에너지로 변환시키는 일종의 발전장치이다. 기존 발전 방식에 비해 높은 전력효율을 기대할 수 있을 뿐만 아니라 공해요 인이 거의 없는 고효율, 청정 발전장치이다[1,2]. 고온 연료전지의 
대표적 형태인 용융탄산염 연료전지(MCFC: Molten Carbonate Fuel Cell, 이하 $\mathrm{MCFC}$ )는 약 $650^{\circ} \mathrm{C}$ 의 고온에서 운전되기 때문에 천연가스, 석탄가스 등의 다양한 연료를 사용할 수 있다는 장점이 있다. 특히, 발전 시 배출되는 고온의 증기를 이용하여 복합발전 이 가능하기 때문에 주요 선진국에서는 $\mathrm{MCFC}$ 를 전력 사업용으로 상 업화하기 위한 연구개발이 활발히 이루어지고 있다[3]. 1980년 대 에는 2차원 스택 모델을 구성하여 온도나 전류밀도의 분포에 대해 모사한 연구와 연료전지의 분극 특성을 이용하여 Scaled-up 방식으 로 실험 결과와 비교한 연구가 있으나 이들 연구는 계산 방식에 있 어서 많은 제약 조건과 가정이 따르는 등 기존 기술의 한계로 인해 정확성이 떨어진다[4,5]. 이후 본격적으로 연구가 활발히 전개된 1990년에는, W. He는 상용 모사기인 CFD의 Speed-up Code를 이 용하여 스택 내의 물질 흐름이나 열 전달형태를 모사하였고, T. Okada는 Matlab의 Simulink를 이용하여 직접 개질 방식의 스택을 모사하였으나 이와 같은 연구들은 주로 Simplified된 모델을 모사 하였다는데 한계점이 있다[6,7]. 2000년대 이후에는 상용화를 위해 보다 구체적이고 다양한 방식의 접근이 이루어졌다. F. Yoshiba는 수치 해석을 통한 전압분포를 분석함으로써 전압 차이에 따른 스택 의 변화를 예측하였다. Michael D. Lukas는 미분 방정식으로 3차원 의 Dynamic 스택 모델을 구성하였으며, 2002년도에는 내부개질형 시스템에 PI 제어 모델을 구성함으로써 부하 변화에 따른 시스템의 성능을 예측하였다 $[8,9,10]$. 주로 스택에 관한 모사는 활발히 이루 어져왔으나, 전체 시스템과의 연계를 고려한 BOP(Balance of Plant) 시스템에 대한 모사는 주로 Simplified 형태로 구성되는 등 연구가 미미한 실정이다. W. Zhang은 Aspen Plus ${ }^{\mathrm{TM}}$ 을 이용하여 SOFC (Solid Oxide Fuel Cell) 시스템을 모사하였다. 이와 같은 연구는 주 요 조업 변수를 고려하여 시스템의 성능을 체계적으로 분석하였다 는 점은 주목할 만하나 정상상태만을 고려한 모델이라는 한계가 있 다[11]. 본 연구에서는 Aspen Dynamics ${ }^{\mathrm{TM}}$ 을 이용하여 용융탄산염 연료전지 발전 시스템을 모사하고 부하 변동이 일어났을 때 시스템 을 안정화시키며 빠른 부하 추종 능력을 갖도록 제어한다. $\mathrm{ACM}^{\mathrm{TM}}$ (Aspen Custom Modeler)을 통해서 스택 모델을 구성한 후, Aspen Plus $^{\mathrm{TM}}$ 을 이용하여 스택과 $\mathrm{BOP}$ 를 연결하여 전체 시스템의 정상상 태를 모사한다. 그리고 Aspen Dynamics ${ }^{\mathrm{TM}}$ 에서 PID제어 방식을 적 용하여 제어 루프를 구성하고 전체 시스템의 발전 효율을 최대로 유 지시키는 운전 조건을 연구하였다.

\section{2. $\mathrm{MCFC}$ 시스템}

용융탄산염 연료전지(MCFC:Molten Carbonate Fuel Cell, 이하 $\mathrm{MCFC})$ 는 탄산리튬 $\left(\mathrm{Li}_{2} \mathrm{CO}_{3}\right)$, 탄산 칼륨 $\left(\mathrm{K}_{2} \mathrm{CO}_{3}\right)$, 탄산나트륨 $\left(\mathrm{Na}_{2} \mathrm{CO}_{3}\right)$ 등의 용융 알칼리 금속 탄산염을 전해질로 사용한다. 단일 전지의 연 료극(Anode)에 수소를, 공기극(Cathode)에는 산소와 이산화 탄소를 도입한다. 수소는 공기극에서연료극으로 전해질을 통해 이동한 음의 전하를 가진 탄산 이온 $\mathrm{CO}_{3}^{2-}$ 과 결합한다. 이 반응으로 방출된 전자 는 외부 회로를 통하여 공기극으로 이동하며 외부로 끌어내는 발전 전류를 구성한다. 한편, 공기극에서는 외부에서 유입된 공기(산소)가 이산화탄소 및 전자와 결합하여 탄산 이온 $\mathrm{CO}_{3}^{2-}$ 을 발생시킨다 (식 (1-3)). 연료극과공기극의 전극반응이 연속적으로 진행되면 외부 회로를 통해공기극에서 연료극 방향으로 전류가 흐르게 되어 지속적 으로 전력을 얻게 된다[12].

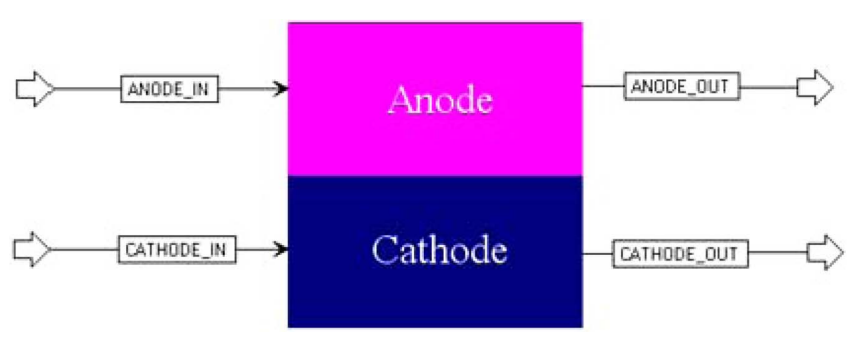

Fig. 1. Stack model in $\mathrm{ACM}^{\mathrm{TM}}$.

Anode: $\mathrm{H}_{2}+\mathrm{CO}_{3}^{2-} \rightarrow \mathrm{H}_{2} \mathrm{O}+\mathrm{CO}_{2}+2 \mathrm{e}^{-}$

Cathode: $\frac{1}{2} \mathrm{O}_{2}+\mathrm{CO}_{2}+2 \mathrm{e}^{-} \rightarrow \mathrm{CO}_{3}^{2-}$

Overall: $\mathrm{H}_{2}+\frac{1}{2} \mathrm{O}_{2}+\mathrm{CO}_{2} \rightarrow \mathrm{H}_{2} \mathrm{O}+\mathrm{CO}_{2}$

\section{2-1. 스택 모델}

Aspen $^{\mathrm{TM}}$ 내에는 스택에 관한 모듈이 따로 지원되는 것이 아니므 로 $\mathrm{ACM}^{\mathrm{TM}}$ (Aspen Custom Modeler)을 통하여 스택 모델을 Fig. 1과 같이 구성하였다. 스택 내에서는 큰 흡열반응인 메탄 개질반응 (Methane Steam Reforming Reaction, 식 (4))과 발열반응인 수성가 스 전환반응(Water Gas Shift Reaction, 식 (5))이 일어난다.메탄 개 질반응은 메탄을 원료로 한 반응으로써 수소와 일산화탄소를 생성하 고 수성가스 전환반응은 일산화탄소를 제거함과 동시에 많은 양의 수소를 생산한다. 이 두 가지 반응은 동시에 진행되는 가역 반응으 로써 평형에 도달하게 되며 여기서, 두 반응의 평형 모델식을 도입 할 수 있다[13].

$$
\begin{aligned}
& \mathrm{CH}_{4}+\mathrm{H}_{2} \mathrm{O} \leftrightarrow \mathrm{CO}+3 \mathrm{H}_{2} \\
& \mathrm{CO}+\mathrm{H}_{2} \mathrm{O} \leftrightarrow \mathrm{CO}_{2}+\mathrm{H}_{2}
\end{aligned}
$$

다음으로 에너지 수지식(Energy balance)을 고려한 스택의 온도는 입구온도와 출구온도를 바탕으로 동특성을간략화하기 위해 구성된 전달 함수(Transfer function)을 도입하여 계산하였다.

$$
\begin{aligned}
& \mathrm{y}=\mathrm{T}_{\text {out }}, \mathrm{u}=\mathrm{T}_{\text {in }} \\
& \frac{\mathrm{y}}{\mathrm{u}}=\frac{\mathrm{k}}{\tau \mathrm{s}+1} \mathrm{e}^{\theta s} \\
& \tau \frac{\mathrm{dy}}{\mathrm{dt}}+\mathrm{y}=\mathrm{ku}(\mathrm{t}-\theta) \\
& \frac{\mathrm{dy}}{\mathrm{dt}}=\frac{1}{\tau}(-\mathrm{y}+\mathrm{ku})
\end{aligned}
$$

스택의동특성을 나타내기 위하여 $\tau$ 의 값을 물질과 에너지 전달 속 도의 차이를 고려하여 설정하였다. 따라서 온도의 $\tau$ 값은 물질 수지 식의 $\tau$ 의 5 배로 설정하였다.

\section{2-2. BOP(Balance of Plant) 시스템}

Aspen Plus ${ }^{\mathrm{TM}}$ 내에서 $\mathrm{BOP}$ 시스템은 연료공급기(LNG, Water, Air), Humihex(Humidified Heat Exchanger), 개질기(Preconverter), 촉매 연소기(Combustor) 등으로 구성된다. 전체 흐름은 Fig. 2에 표시된 것처럼 스택을 중심으로 연료극(Anode)과 공기극(Cathode) 흐름으 로 구분되며 각각의 흐름에는 재순환(Recycle, Recirculation) 흐름을 추가로 고려하였다.

$\mathrm{MCFC}$ 시스템의 입구 흐름은 천연가스, 물, 공기로 구성된다. 이 들의 입구 조건은 전류밀도 $1,200 \mathrm{~A} / \mathrm{cm}^{2}$ 기준으로 계산되었다. 


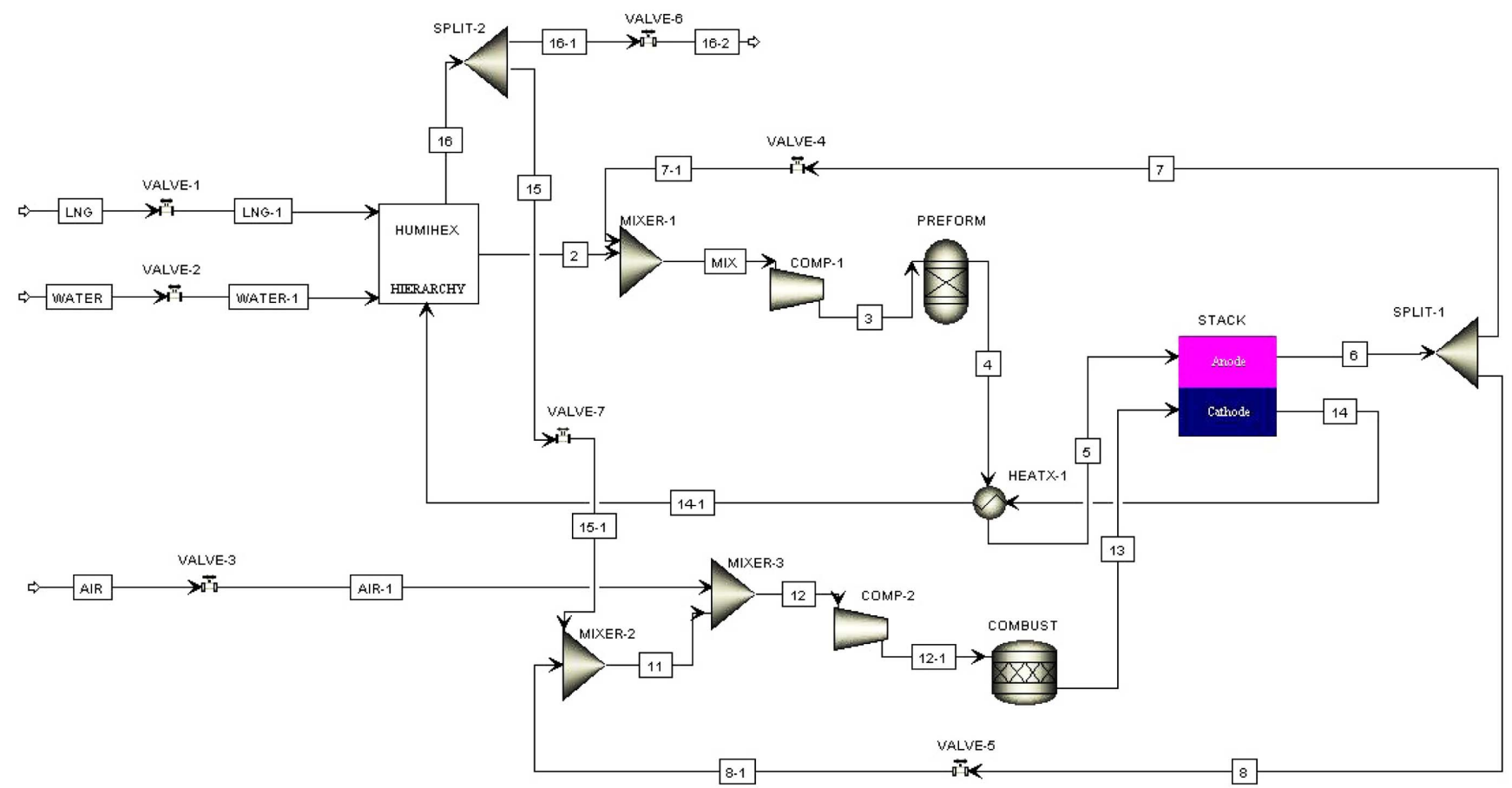

Fig. 2. MCFC system in Aspen Plus ${ }^{\mathrm{TM}}$.

$\mathrm{MCFC}$ 시스템에 공급되는 연료는 천연가스와 고온의 증기(Steam)가 혼합된 형태로써 이 혼합된 흐름은 Preconverter 내에서 초기 반응물 질 인 수소로 개질 된다. 증기는 Preconverter 내 촉매개질 반응에서 $\mathrm{CO}$ 의 형성을 방지하는 역할을 하기 때문에 과량의 증기가 주입되며, 증기의 양은 $\mathrm{S} / \mathrm{C}$ (Steam to carbon) ratio에 의해 결정된다. Preconverter 에서는 메탄보다 세탄가가 높은탄화수소(Hydrocarbon) 즉, $\mathrm{C}_{2}$ 이상 의 탄화수소를 제거하는 Cracking 반응이 일어나 Soot formation을 방지하고 부분적으로 약 5 10\%의 메탄 개질반응이 일어난다.촉매 연소기는 탄산염 이온 $\left(\mathrm{CO}_{3}^{2-}\right)$ 을 생성하는데 필요한 예열된 산소 $\left(\mathrm{O}_{2}\right)$ 와 이산화탄소 $\left(\mathrm{CO}_{2}\right)$ 를 공기극(Cathode)에 공급해주는 역할을 한다. 연료극(Anode)에서는 약 50 80\%의 연료가 반응하고 약 $20-50 \%$ 정도의 미 반응된 연료가 tail gas로 나온다. 이 때, tail gas 내의 연료(수소) 가촉매연소기에서 남은 수소를 전부 연소시키는 반응이 일어나 주입 된 공기(Stream AIR)의 온도를 높이게 된다.

\section{Sensitivity Analysis}

Aspen Plus ${ }^{\mathrm{TM}}$ 내 Model Analysis를 이용하여 주요 조업변수에 따 른 $\mathrm{MCFC}$ 시스템의 성능을 분석하였다. 주요 조업변수로는 연료이 용률, 전류밀도, $\mathrm{S} / \mathrm{C}$ ratio, 재순환 흐름 비를 선택하였고 이에 따른 시스템의 성능을 분석한 결과는 다음과 같다.

\section{3-1. 전류 밀도 영향}

Fig. 3 의 결과를 살펴보면 전류밀도가 0.06 에서 0.18 까지 증가함에 따라 전극 손실도 같이 증가하여 셀 전압과 효율은 감소하는 경향을 나타낸다. 반면 전력량은 전류밀도와 스택 전압의 곱에 비례하므로 셀 전압 감소 폭에 비해 전류밀도의 증가 폭이 크고 전류밀도와 같 이 증가함을 알 수 있다. 전류밀도가 증가함에 따라 산소를 공급하 는 역할을 하는 공기의 공급량도 같이 증가하는 것을 확인할 수 있 는데 이는 스택의 온도를 떨어뜨리는 원인이 된다. 그러므로 전류밀

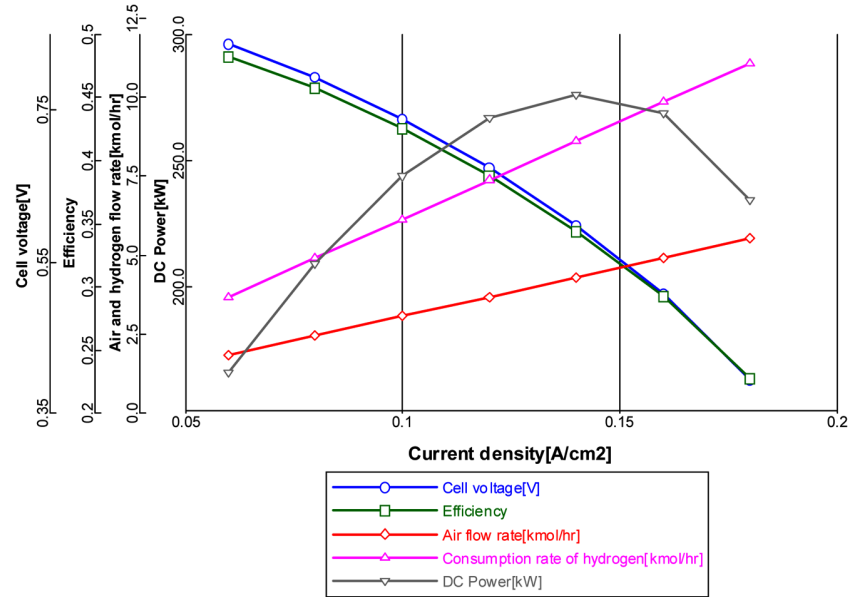

Fig. 3. Effects of Current density on the Cell voltage.

도에 따른 시스템의 특성을 분석해본 결과, 전류 밀도가 낮을 때 오 히려 높은 효율을 기대할 수 있음을 확인할 수 있다.

그러나 이는 또한 낮은 전력량을 야기하므로 높은 출력을 기대하 기 위해서는 Cell 수를 증가시켜야 하므로 결국, Capital cost를 증가 시키는 원인이 된다.

\section{3-2. $\mathrm{S} / \mathrm{C}$ ratio 영향}

$\mathrm{S} / \mathrm{C}$ ratio는 물 분자와 $\mathrm{C}$ (탄소) 원자의 비로써 수증기 개질반응에 따른 메탄과 수소 및 연료이용률에 영향을 끼친다. $\mathrm{S} / \mathrm{C}$ ratio가 증가 한다는 것은 곧 물 분자량의 증가를 의미하므로 $\mathrm{S} / \mathrm{C}$ ratio를 1.3 에서 4.6까지 증가시킴에 따라 물의 양도 같이 증가하게 된다. 따라서 Preconverter 내의 수증기 개질 반응이 촉진되므로 반응물인 메탄이 감소하고 생성물인 수소의 양이 증가하게 된다. 따라서 수소의 증가 는 곧 공급되는 연료의 양이 증가함을 의미하므로 이는 연료이용률 의 감소시키는 원인이 된다. 따라서 너무 높은 값의 $\mathrm{S} / \mathrm{C}$ ratio는 결 


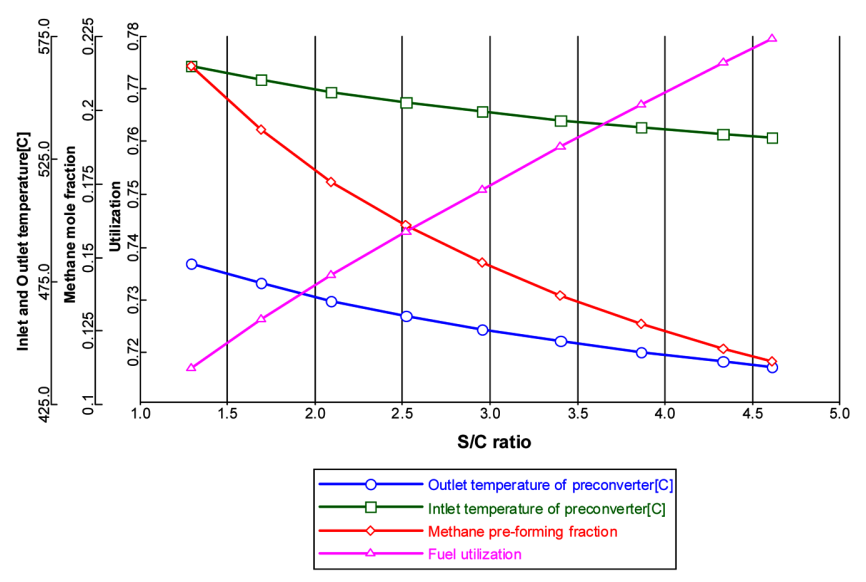

Fig. 4. Effects of S/C ratio on the Utilization, Methane pre-reforming fraction and inlet and outlet temperature of Preconverter.

국 더 큰 크기의 Preconverter의 설치를 요구하게 되므로 Capital cost 를 증가시키는 원인이 된다. 또한 Fig. 4에서 제시된 것과 같이 개질 반응은 큰 흡열반응으로써 반응이 촉진됨에 따라 Preconverter의 입 구 및 출구의 온도를 감소시키고 이는 곧 스택의 입구 온도를 낮추 는 결과를 초래한다.

\section{3-3. 연료이용률 영향}

연료이용률은 중요한 조업변수 중의 하나로서 전체 시스템의 효 율에 큰 영향을 끼친다.연료이용률(Utilization, $\left.\mathrm{U}_{f}\right)$ 은 다음과 같이 정 의된다.

$$
\mathrm{U}_{f}=\frac{\text { 전기화학반응에 의한 수소소모속도 }\left(\mathrm{q}_{\mathrm{H}_{2}}\right)}{\text { 실제연료전지에 수소공급속도 }\left(\mathrm{q}_{\mathrm{H}_{2}}{ }^{\prime}\right)}
$$

연료이용률에 따른 효율 및 수소공급속도의 변화를 Fig. 5에 도시 하였다. 연료이용률을 약 0.6 에서 0.94 까지 증가시켰을 때 수소가

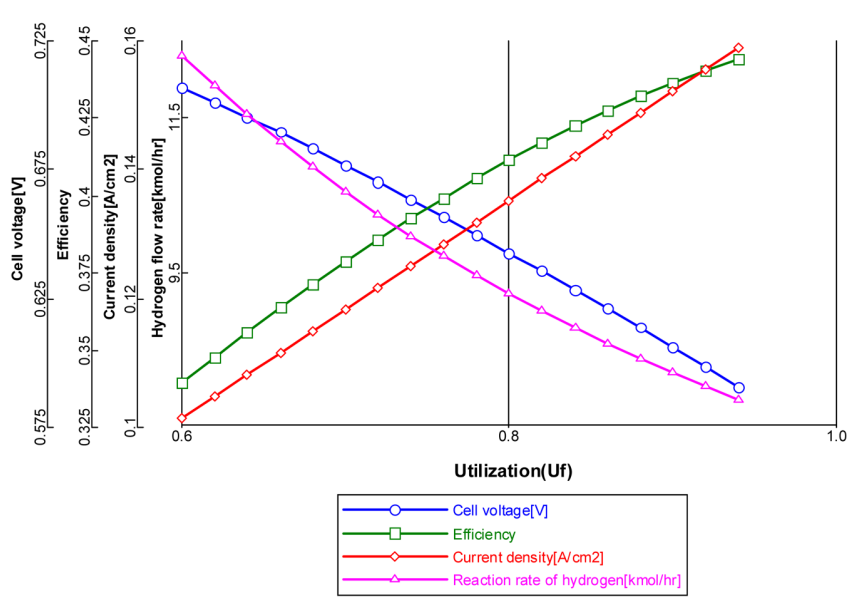

Fig. 5. Effects of $U_{f}$ on the Cell voltage, Efficiency, Current density and Reaction rate of hydrogen.

많이 소모됨에 따라 연료극으로 들어가는 수소공급 속도가 감소하는 경향을 보였다. 반면 효율은 셀 전압과 연료이용률의 곱에 비례하므 로 연료이용률이 증가함에 따라 같이 증가하는 경향을 나타내었다. 이는 연료가 많이 소모됨에 따라 전극 손실(Polarization loss)이 증가 하여 셀 전압은 감소하게 되나, 셀 전압이 효율에 미치는 영향은 크 지 않기 때문에 효율은 연료이용률에 비례하는 것임을 확인할 수 있 다. 또한 수소소모속도가 증가함에 따라 전류밀도도 같이 증가하는 것을 확인할 수 있다.

\section{4. 동적 모사 및 제어}

Aspen Dynamics ${ }^{\mathrm{TM}}$ 에서MCFC 시스템의 동적모사를 수행하였다. 제어하고자 하는 조업 변수는 총 3 개로서 메탄 유량, $\mathrm{S} / \mathrm{C}$ ratio에 따 른 물 유량, 스택 온도이다. 따라서 총 3개의 PID Controller를 추가 하였으며 Fig. 6에 도시하였다.

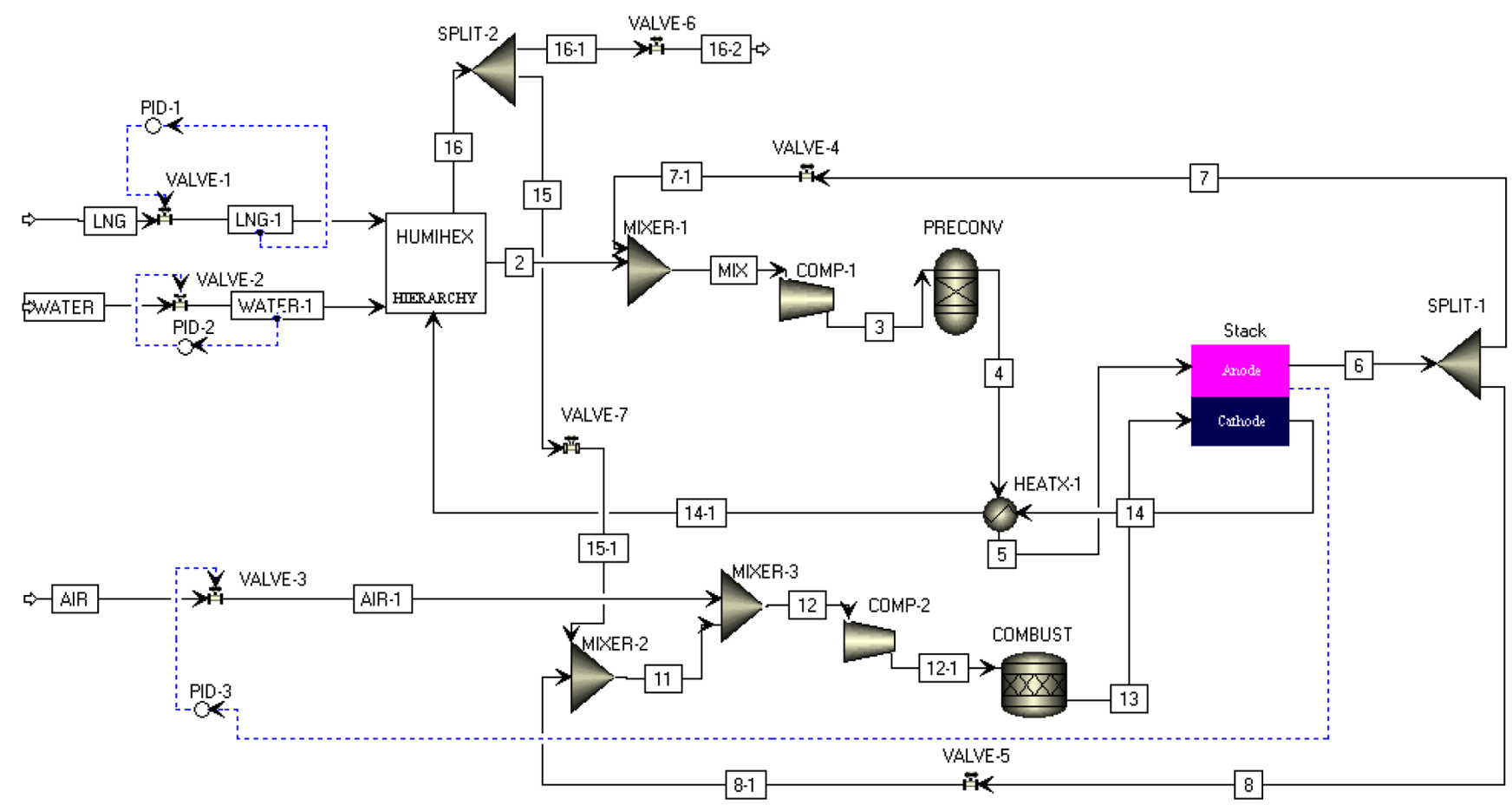

Fig. 6. Control loop of MCFC system in Aspen Dynamics ${ }^{\text {TM }}$. 
Table 1. Parameter Tuning of Controller

\begin{tabular}{ccccc}
\hline \hline \multirow{2}{*}{ Controller } & \multicolumn{3}{c}{ Tuning parameter } & \multirow{2}{*}{$\begin{array}{c}\text { Controller } \\
\text { mode }\end{array}$} \\
\cline { 2 - 4 } & Gain & Integral time & Derivative time & Reverse \\
\hline PID-1 & 0.943 & 2.4 & 0.6 & Reverse \\
PID-2 & 1.206 & 2.4 & 0.6 & Direct \\
PID-3 & 3.146 & 2.4 & 0.6 & \\
\hline
\end{tabular}

PID-1은 공급되는 메탄 유량을 제어한다. 연료인 수소의 공급속도 는 메탄의 유량에 의해 조절된다. 따라서 메탄 유량을 조절함으로써 연료이용률을 $72 \%$ 로 일정하게 유지하는 것을 제어 목표로 한다. 다 음으로 PID-2는 1.68로 설정된 S/C ratio에 맞게 물의 공급량을 제어 한다. PID-3는 스택 온도를 제어한다. 공기는 과량으로 주입되어 산 소를 공급하고 스택 온도를 조절하여 Hot spot과 같이 스택의 과열 로 인해 생기는 문제를 방지한다. 각각의 제어기에 대한 Parameter Tuning은 Open loop test를 통한 Auto tuning 방법을 이용하였으며 각각의 data는 아래 Table 1에 나타내었다. 세 가지 사례를 통해서 실 제 조업 상황에서의 변화를 예측하고 사례별 제어전략을 구성하였다.

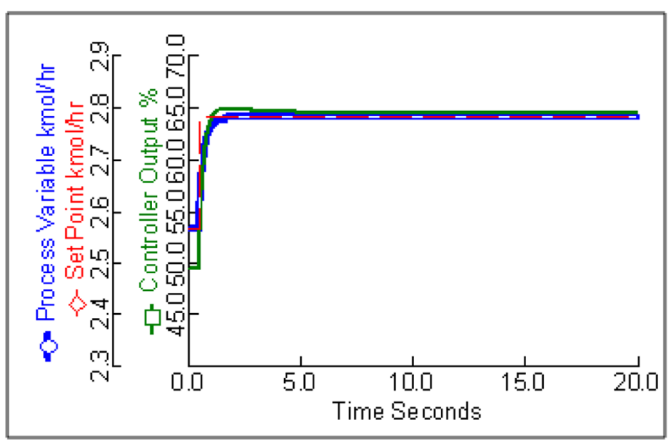

(a) PD-1 (+100A/cm²)

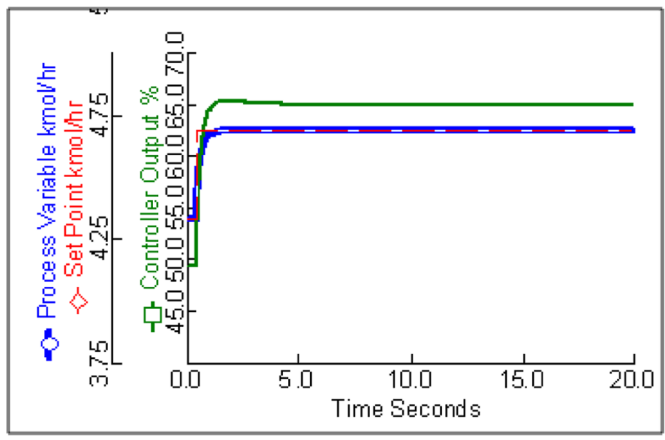

(b) PID-2 (+100A/cm²)

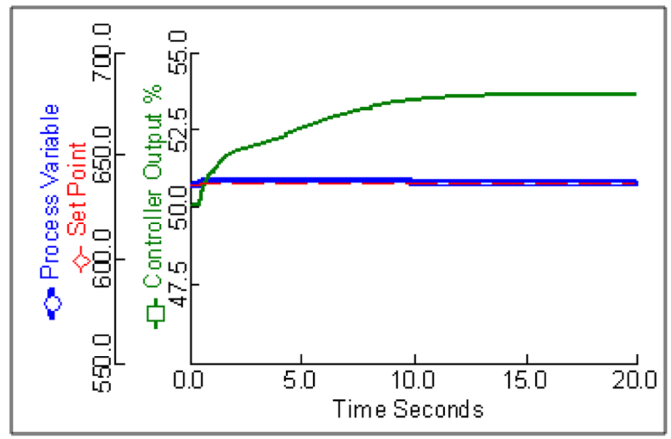

(c) PID $3\left(+100 A / \mathrm{cm}^{2}\right)$

Fig. 7. Simulation results by increasing/decreasing current density.

\section{4-1. 부하 변화}

전류 밀도가 변하였을 경우 $\left( \pm 100 \mathrm{~A} / \mathrm{m}^{2}\right)$, 즉 부하 변동 시 제어변 수와 조작 변수의 거동을 나타내었다. 이 경우는 실제 조업 시 부하 가 변화하게 되면 연료소비량이 일시적으로 증가 또는 감소하게 되 어연료이용률에 영향을 주므로이를 정상으로 유지하기 위한 제어를 보여주는 예이다. 먼저 전류 밀도를 약 $100 \mathrm{~A} / \mathrm{m}^{2}$ 증가시켰을 경우는 시스템은 Fig. 7의 (a) (c)와 같은 거동을 보인다. PID-1 제어기에서 제어변수인 메탄유량을 증가한 연료 공급량에 맞게 유지시킴으로써 수소공급속도를 조절하여 연료이용률을 $72 \%$ 로 유지하도록 제어한 다. 또한 PID-2 제어기에서는 증가한 메탄 유량만큼 물의 유량도 S/ C ratio 1.68만큼 증가한 후 일정하게 유지한다. 또한 PID-3 제어기 에서는 과잉 공기를 제어하는 역할을 한다. 부하가 증가함에 따라 반 응이 많이 일어나게되어 스택의 온도는 증가한다. 만약 이 때 스택 온도가 과도하게 높아지게 되면 Hot spot이나 전해질이 부식되는 현 상이 발생하므로 Excess Air 즉, 남은 수소를 연소시키는 역할을 하 는 산소 이외의 과량으로 공급된 산소가 스택 온도를 낮추어주는 역 할을 한다. 따라서 이 때 스택 온도는 약 $636.7^{\circ} \mathrm{C}$ 로 제어된다. 반대

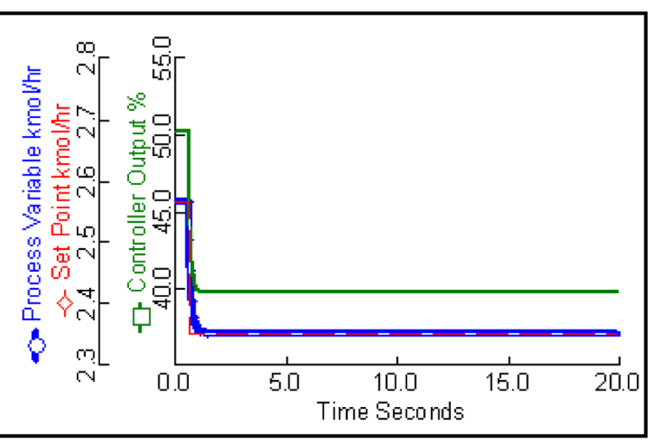

(d) PID-1 (-100A/cm²)

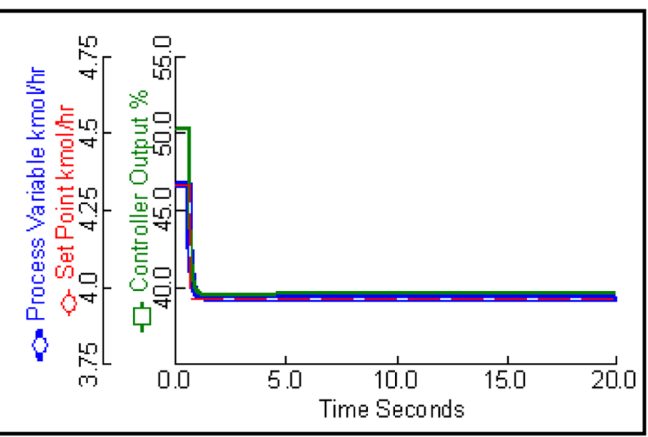

(e) PID-2 (-100A/cm²)

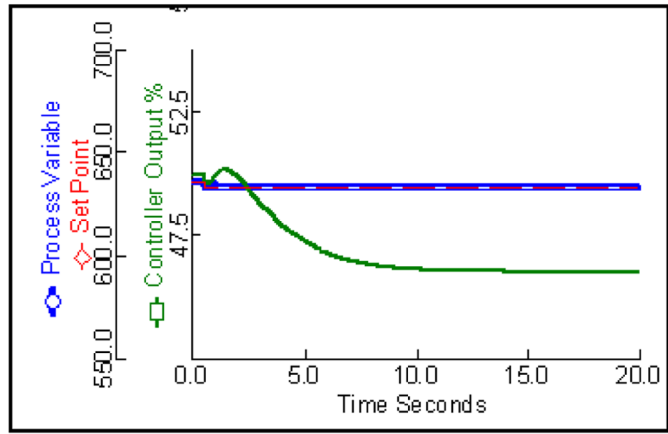

(f) PID-3 (-100A $\left./ \mathrm{cm}^{2}\right)$ 
로 전류밀도를 약 $100 \mathrm{~A} / \mathrm{m}^{2}$ 감소시켰을 경우(Fig. 7의(d) (f)) 먼저 부하가 감소함에 따라 연료소비량과 연료공급량 이 감소하다. 따라 서 PID-1 제어기에서 감소한 메탄유량을 일정하게 유지시킴으로써 수소공급속도를 조절하여 연료 이용률을 $72 \%$ 로 유지하도록 제어한 다. PID-2 제어기에서는 S/C ratio 1.68만큼 감소한 메탄 유량에 비 례하여 물의 유량은 감소한 후 유지된다. PID-3 제어기에서는 감소 한 스택의온도를 제어하기 위하여 Excess Air의 유량을 감소시킴으 로써 약 $633.7^{\circ} \mathrm{C}$ 로 스택 온도를 유지시킨다.

\section{4-2. 설정점(Set Point) 변화}

부하 변화가 없을 때, 메탄유량과 스택 온도의 설정점에 변화를 주 어 시스템의 성능 변화를 예 측해보았다. 먼저 메탄유량의 설정점이 변하였을 경우 $( \pm 10 \%)$, 제어 변수와 조작 변수의 거동을 Fig. 8 에 나 타내었다. 이 경우는 부하 변화는 없으나 메탄유량의 설정점에 변화 를 주게 되면 수소생산량과 출력전압에 영향을 끼치게 되므로 이 때 시스템을 정상적인 출력 범위 내에서 조업하기 위한 제어를 보여주 는 예이다. 먼저 메탄유량의 설정점을 약 $10 \%$ 증가시켰을 때 시스

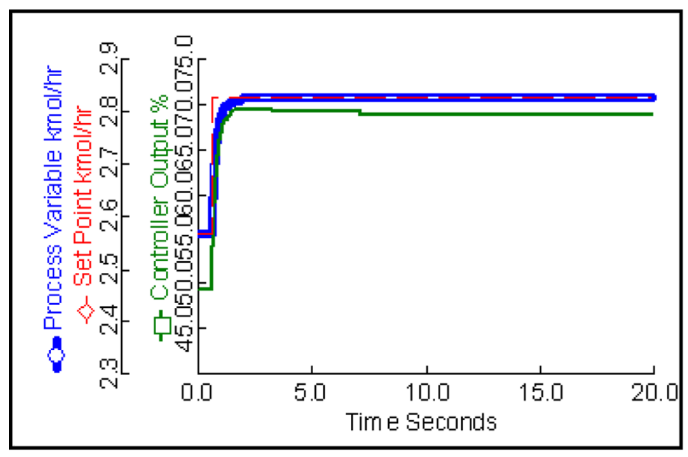

(a) PID-1 (+10\%)

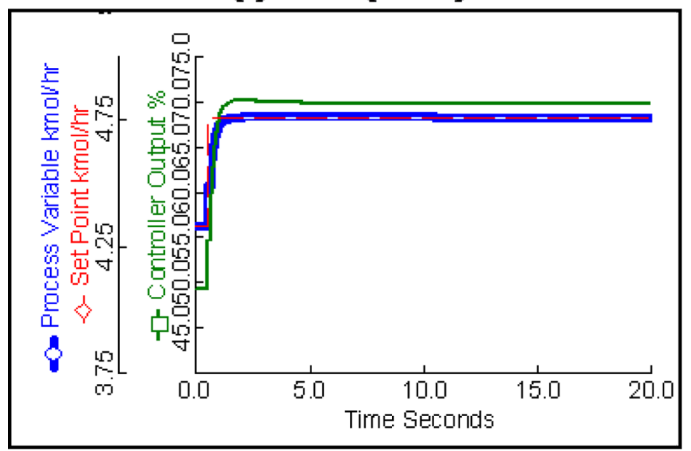

(b) PID-2 (+10\%)

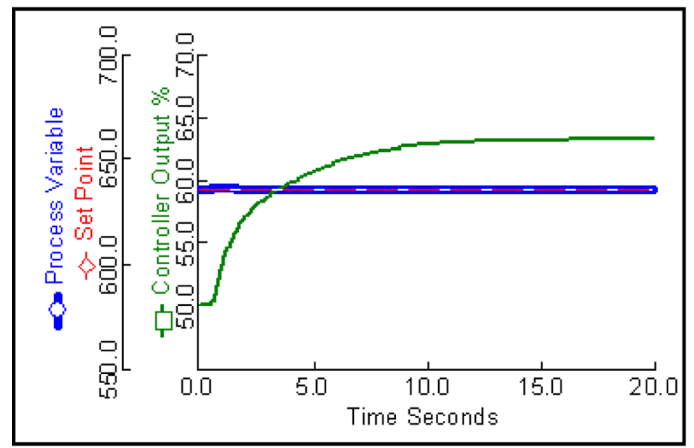

(c) PID- 3 (+10\%)
템은 Fig. 8의 (a) (c)와 같은 거동을 보인다. PID-1 제어기에서는 증 가한 설정점만큼 메탄유량이 증가하게 되고 이는 수소 공급속도의 증가를 야기시킨다. 따라서 부하변화가 없으므로 수소소모속도가 일 정한 상태에서 수소의 공급속도만 증가하게 되므로 연료이용률은 $72 \%$ 에서 약 $65 \%$ 까지 감소하게 된다. PID-2 제어기에서는 증가한 메탄 유량만큼 물의 유량도 S/C ratio(1.68)에 따라 증가하여 일정하 게 유지된다. 반응이 많이 진행됨에 따라서 반응열이 발생하고 결국 스택의 온도는 올라가게 된다. PID-3 제어기에서는 Excess Air의 유 량을 늘려스택 온도를 원래대로 낮추어 $635.2{ }^{\circ} \mathrm{C}$ 로 유지한다. 다음 으로 메탄유량의 설정점을 약 $10 \%$ 감소시켰을 때 PID-1 제어기 에 서는 설정점의 변화에 따라 메탄유량이 감소하게 되고 결국 수소의 공급속도를 감소시키게 되므로 연료이용률은 $72 \%$ 에서 약 $80 \%$ 까지 증가하게 된다. 또한 PID-2 제어기에서는 감소한 메탄 유량만큼 물 의 유량도 $\mathrm{S} / \mathrm{C}$ ratio(1.68)에 따라 감소한다. 반응양의 감소에 따라 스택의 온도도 감소하여 PID-3 제어기에서는 Excess Air의 유량을 줄여 스택 온도를 원래대로 높여 $635.2^{\circ} \mathrm{C}$ 로 유지한다(Fig. 8 의 (d) (f)).

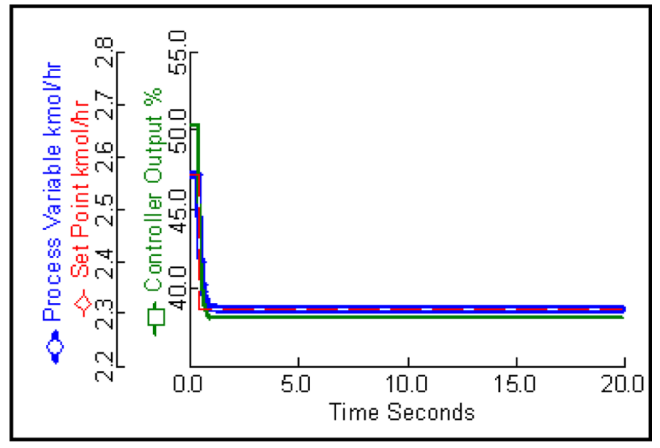

(d) PID-1 (-10\%)

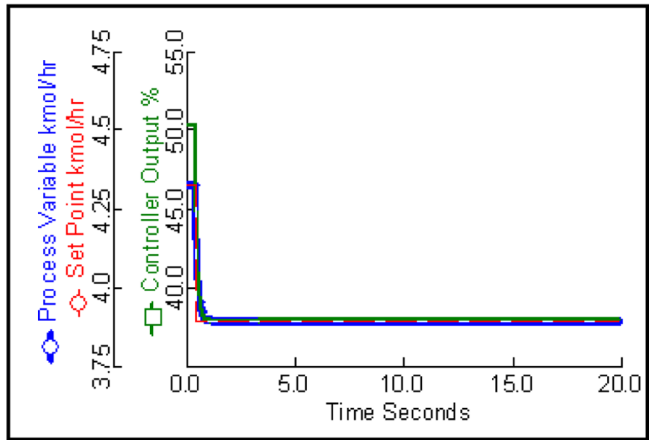

(e) PID-2 (-10\%)

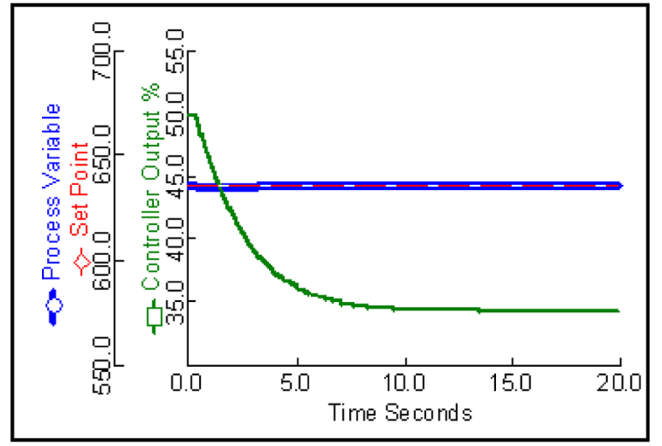

(f) PID-3 (-10\%)

Fig. 8. Simulation results by increasing/decreasing set point of methane flow rate. 


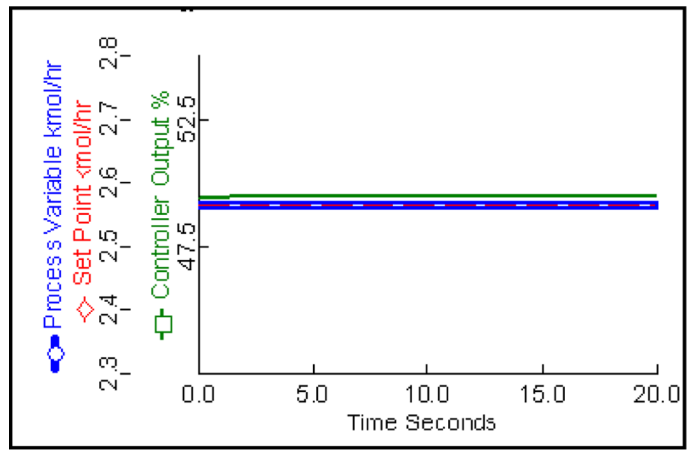

(a) PID-1 (+10C)

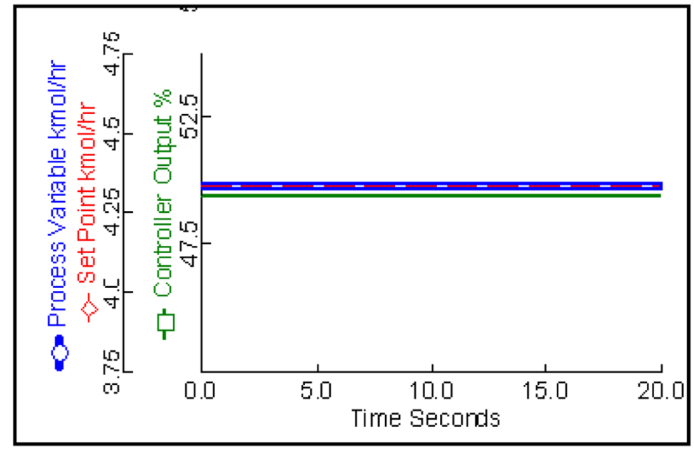

(b) PID-2 (+10C)

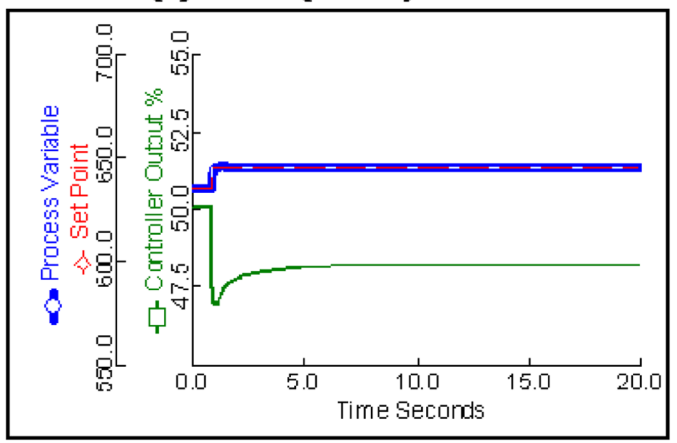

(c) PID-3 (+10 C)

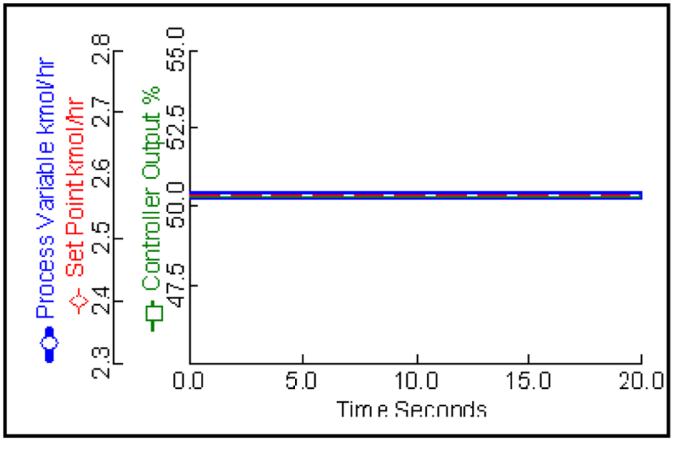

(a) PID-1 (-107)

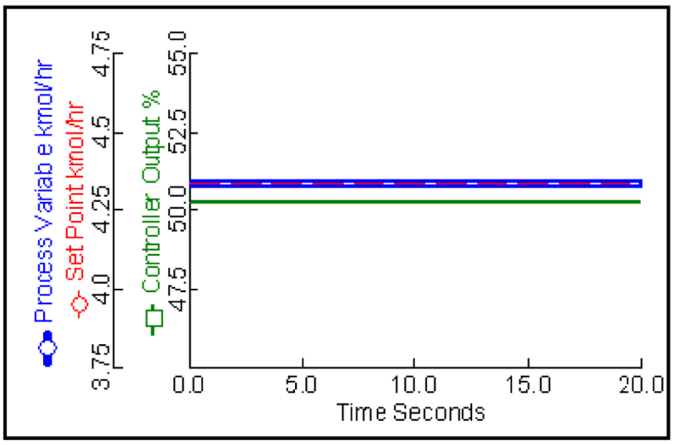

(b) PID-2 (-10C)

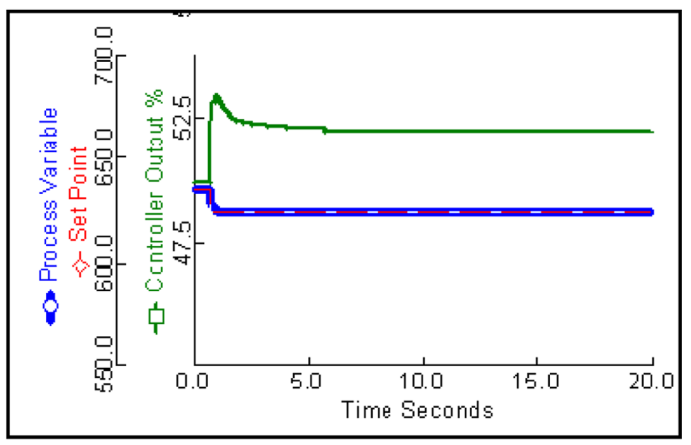

(c) PID-3 (-10T)

Fig. 9. Simulation results by increasing/decreasing set point of stack's temperature.

다음은 스택온도의 설정점을 변화시켜 보았다. Fig. 9 에스택 온도 의 설정점이 변하였을 경우 $\left( \pm 10{ }^{\circ} \mathrm{C}\right)$, 제어 변수와 조작 변수의 거동을 나타내었다. 이 경우는 스택온도가 변화하게 되면 용융탄산염의 활 동도나 전해질의 부식에 영향을 끼치게 되므로 이 때 시스템의 성능 을 높게 유지하면서 정상적인 출력 범위 내에서 조업하기 위한 제어 를 보여주는 예이다. 먼저 스택온도의설정점을 약 $10^{\circ} \mathrm{C}$ 증가시켰을 때 PID-1과 PID-2에서 나타나는 변화는 거의 없으며 이 때 PID-3 제 어기에서 Excess Air의 유량을 줄여 스택온도를 설정 점에 맞추어 유지한다. 다음으로스택온도의설정점을 약 $10{ }^{\circ} \mathrm{C}$ 감소시켰을 때 PID-3 제어기에서 Excess Air의 유량을 늘려 스택온도를 설정점에 맞추어 감소시킨다.

\section{4-3. 재순환 흐름비의 변화}

부하 및 설정점의 변화가 없을 때, 재순환 흐름 비가 시스템의 성 능에 미치는 영향에 대해 알아보았다.재순환 흐름비가 변화하게 되 면 연료극으로 유입되는 유량이 변화하게 되고 공기극으로 유입되는
미반응된 수소의 양이 변화하여 스택온도에 영향을 미치게 된다. 따 라서 본 사례연구는 이러한 경우에 시스템을 정상적인 출력 범위 내 에서 조업하기 위한 제어를 보여주는 예이다. Fig. 10에 재순환 흐름 의 유량이변하였을 경우 $( \pm 10 \%)$ 제어변수와 조작변수의 거동을 나타 내었다.먼저 Anode recycle stream의 재순환 흐름비를 $10 \%$ 증가하 면, 스택의 연료극으로 유입되는 유량이 증가하게 된다. 따라서 PID1 제어기에서는 부하변화 없이 수소 공급량만 증가하게 되므로 메탄 유량을 원래 값에 맞게 유지함에 따라 연료이용률을 일정하게 유지 시킨다. 또한 PID-2 제어기에서도 $\mathrm{S} / \mathrm{C}$ ratio(1.68)에 따라 일정하게 물의 유량을 제어한다. 반면, 연료극의 재순환 비가 증가함에 따라 공기극의 재순환 비는 감소한다.따라서 재순환되는 미반응 수소의 양이 감소하게 되므로 연소반응이 덜 일어나게 되어 스택온도의 감 소를 초래한다. 따라서 PID-3 제어기에서는 공기 유량을 감소시킴으 로써 스택 온도를 원래 값인 $635.2{ }^{\circ} \mathrm{C}$ 로 유지시킨다(Fig. 10의(a) (c)). 다음으로 재순환 흐름비를 $10 \%$ 감소시키면스택의연료극으로 유입되는 유량이 감소한다. 따라서 PID-1와 PID-2 제어기에서는 연 


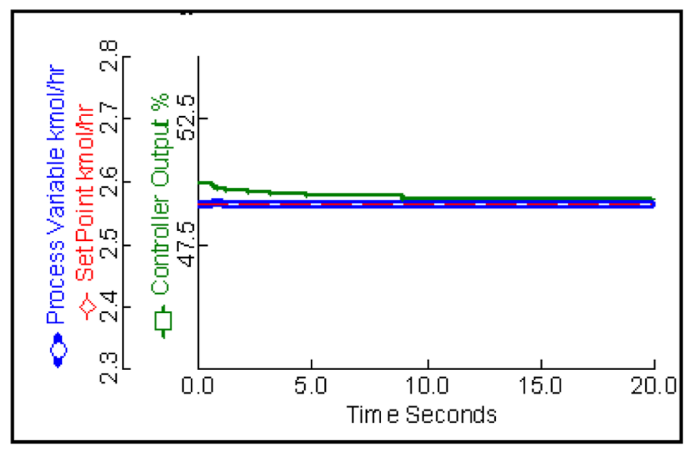

(a) PID-1 (+10x)

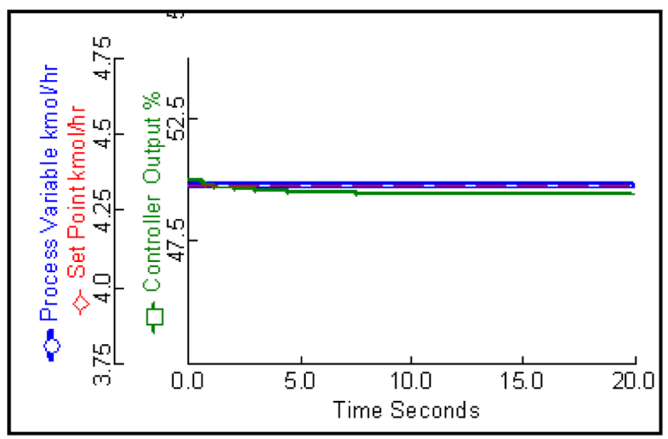

(b) PID-2 (+10 7 )

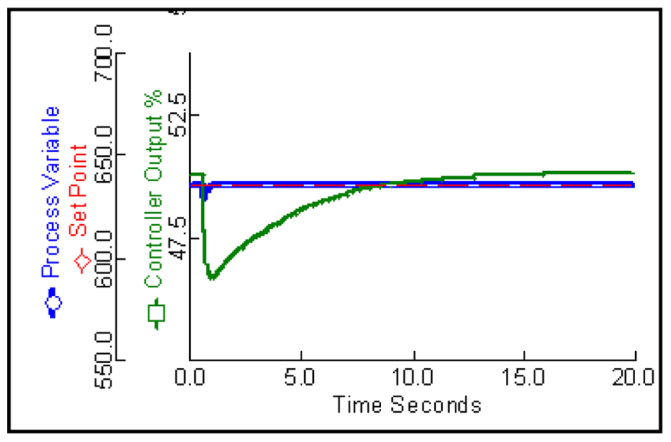

(c) PID- $3(+10 \%)$

Fig. 10. Simulation results by increasing/decreasing recycle ratio.

료이용률을 일정하게 유지시키기 위해 메탄 유량과 S/C ratio에 따른 물의 유량을 제어하게 된다. 또한 공기극의 재순환 비가 감소함에 따 라 스택온도는 증가하게 된다. 따라서 PID-3 제어기 에서는 공기 유 량을 증가시켜 스택온도를 원래 값인 $635.2^{\circ} \mathrm{C}$ 로 제어한다(Fig. 10 의 (d) (f)).

\section{5. 결 론}

본 연구에서는 Aspen $^{\mathrm{TM}}$ 을 이용하여 용융탄산염 연료전지 발전시 스템을 모사하였다. 스택 모델은 $\mathrm{ACM}^{\mathrm{TM}}$ (Aspen Custom Modeler) 내에서 $\mathrm{CH}_{4}, \mathrm{H}_{2}, \mathrm{O}_{2}, \mathrm{H}_{2} \mathrm{O}, \mathrm{CO}_{2}$ 의 key components를 도입하여 평형 모델식을 구성하였고, 부하 변화에 따른 시스템의 영향을 고려하기 위해 $\mathrm{H}_{2} \mathrm{O}, \mathrm{CO}_{2}, \mathrm{H}_{2}$ 의 물질 구성식에, 소모되는 수소의 몰 유량을 추 가로 고려하여 전류밀도에 따른 반응량의 변화를 나타내었다. 다음으로 Aspen Plus ${ }^{\mathrm{TM}}$ 에서 스택모델과 $\mathrm{BOP}$ 시스템을 연결하여 약 $266.7 \mathrm{~kW}$ 급 연료전지 발전 시스템을 모사하였다. Sensitivity analysis를 통해 연료이용률, 전류밀도, S/C ratio, 재순환 흐름 비와 같은 주요 조업 변수에 따른 셀 전압, 전력, 효율과 같은 시스템의 성능을 분석하였

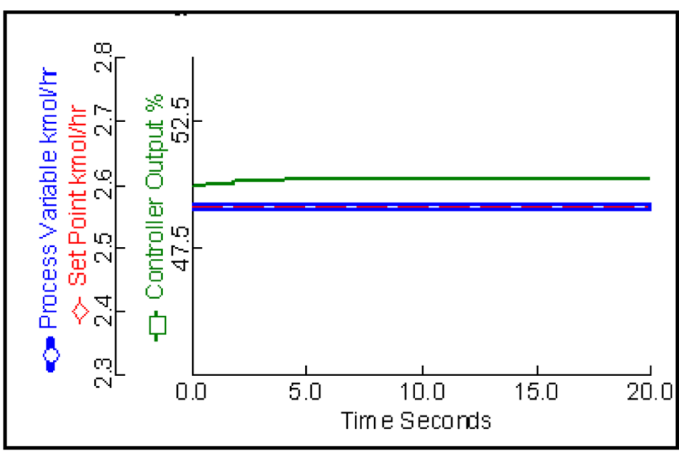

(d) PID-1 (-10\%)

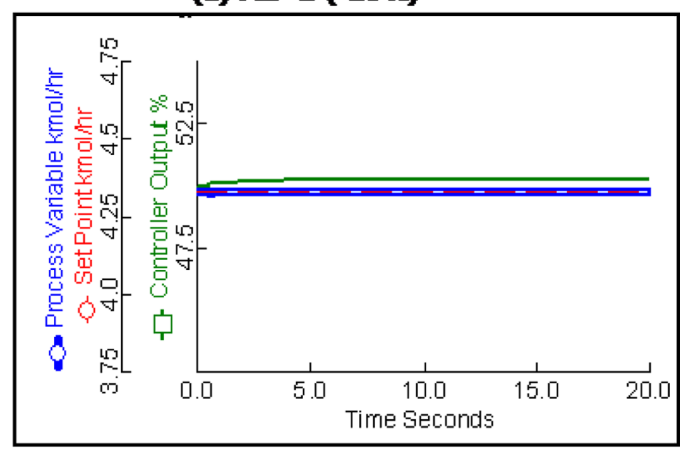

(e) PID-2 (-10 * $)$

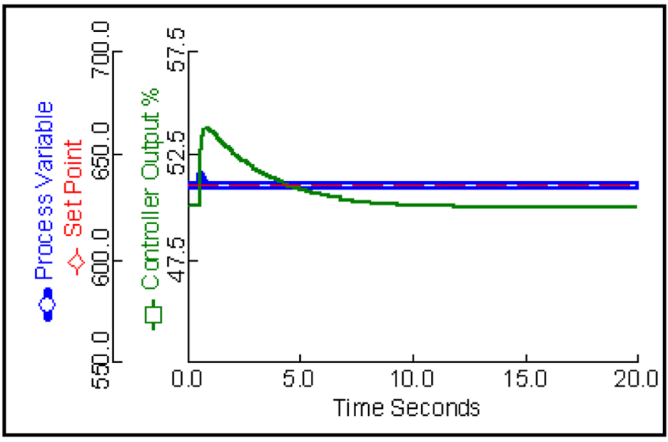

(f) PID-3 (-10 *3)

고 연료이용률 $72 \%$, 전류밀도 $1200 \mathrm{~A} / \mathrm{m}^{2}, \mathrm{~S} / \mathrm{C}$ ratio 1.68 의 $\mathrm{MCFC}$ 시스템의 기준 값으로 설정하였다.

Aspen Dynamics ${ }^{\mathrm{TM}}$ 에서는 전통 제어방식인 PID 방식을 적용하여 총 3 개의 PID 제어기 추가하여 제어루프를 구성하였다. 먼저, PID1 제어기에서는 현재 기준 값인 $72 \%$ 의 연료이용률을 유지하기 위하 여 메탄유량을 제어하였다. 예를 들어 사례연구 중 부하가 증가하는 경우, 수소 소비량이 증가함에 따라 연료이용률이 증가하게 된다. 따 라서 이 때 메탄유량도 같이 증가한 값으로 유지시키며 결과적으로 현재 설정 값인 $72 \%$ 의 연료이용률을 유지하였다. PID-2 제어기에서 는 1.68 의 기준 값을 갖는 $\mathrm{S} / \mathrm{C}$ ratio의 비에 따라 메탄 유량이 변화 한 양만큼 물의 공급량을 제어하였다. PID-3 제어기에서는 Excess Air의 양을 조절하여 스택의 온도를 제어하였다. 스택의 온도는 현재 약 $635^{\circ} \mathrm{C}$ 로써 용융탄산염 연료전지와 같이 고온 연료전지의 경우, 스택의 온도가 너무 낮은 경우에는 용융탄산염의 활동도가 저해되고 반대로 스택의 온도가 너무 높게되면 전해질 부식이 증가하여 스택 의 성능을 떨어뜨리게 되므로 스택 온도 제어는 성능 향상에 있어서 중요한 의미를 갖는다. 이와 같이 Aspen Dynamics ${ }^{\mathrm{TM}}$ 에서 구성한 제 어루프는 실제 조업 시 갑작스러운 부하변화나 연료공급량의 변화에 
따른 시스템의 성능을 예측하거나 분석하는데 유용하게 사용될 것이 라고 예상된다. 또한 본 연구에서는 전통제어방식인 PID방식만을 적 용하였으나 추후에 MPC(MPC: Model Predictive Control)를 도입한 다면 각각의 주요 조업변수에 따른 최적화를 구현하여 시스템의 성 능을 좀 더 체계적으로 분석하여 제어 성능평가의 향상을 가져오리 라 예상된다.

\section{감 사}

본 연구는 2008년도 지식경제부의 재원으로 한국에너지 기술평가 원(KETEP)의 지원을 받아 수행한 연구 과제입니다(2008-N-FC12$\mathrm{J}-04-2100)$.

\section{사용기호}

k : Steady-state gain

$\mathrm{q}_{H_{2}} \quad$ : Consumption rate of hydrogen[kmol/hr]

$\mathrm{q}_{H_{2}^{\prime}} \quad$ : Reaction rate of hydrogen[kmol/hr]

$\mathrm{T}_{\text {in }}, \mathrm{T}_{\text {out }}$ : Inlet and Outlet temperature of stack[K]

$\mathrm{u} \quad$ : Deviation variable of input

$\mathrm{U}_{f} \quad$ : Fuel utilization

y : Deviation variable of output

$\tau \quad:$ Time constant[sec]

\section{참고문헌}

1. Kirubakaran, A., Jain, S. and Nema, R. K., "A Review on Fuel Cell Technologies and Power Electronic Interface,' Renew. Sust. Energ. Rev., 13, 2430-2440(2009).

2. Lim, H. C., "Development of a $100 \mathrm{kw}$ Class Molten Carbonate Fuel Cell System, Journal of Power Sources: Step 1: Operation and Analysis of 25 kW MCFC system,', J. Power Sources., 283,
$16-27(2000)$.

3. Lim, H. C. and Koh, J. H., "Operation Characteristics and Analysis of Temperature Gradients in a 5-kW Molten Carbonate Fuel Cell Stack,' Trans. the Korean Hydrogen \& New Energy Society, 10(2), 107-118(1999).

4. Wolf, T. L. and Wilemski, G., "Molten Carbonate Fuel Cell Performance Model,', J. Electrochem. Soc, 130, 48-55(1983).

5. Sampath, V., Sammells, A. F. and Selman, J. R., "A Performance and Current Distribution Model for Scaled-up Molten Carbonate Fuel Cell,' J. Electrochem. Soc, 127, 79-85(1983).

6. Lukas, M. D., Lee, K. Y. and Ghezel-Ayagh, H., "Development of a Stack Simulation Model for Control Study on Directreforming Molten Carbonate Fuel Cell Power Plant', IEEE Trans. Energy Conversion, 14(4),1651-1657(1999).

7. He, W., "The Dynamic Performance of a Molten Carbonate Fuel Cell in Power-generation Systems,' J. Power Sources, 52, 179184(1994).

8. Yoshiba, F., Abe, T. and Watanabe, T., "Numerical Analysis of Molten Carbonate Fuel Cell Stack Performance: Diagnosis of Internal Conditions Using Cell Voltage Profiles,' J. Power Sources, 87, 21-27(2000).

9. Lukas, M. D., Lee, K. Y. and Ghezel-Ayagh, H., "An Explicit Dynamic Model for Direct Reforming Carbonate Fuel Cell Stack,' IEEE Trans. Energy Conversion, 16(3), 289-295(2001).

10. Lukas, M. D., Lee, K. Y. and Ghezel-Ayagh, H., "Modeling and Cycling Control of Carbonate Fuel Cell Power Plants,' Control Engineering Practice, 10(2), 197-206(2002).

11. Zhang, W., Croiset, E., Douglas, P. L., Fowler, M. W. and Entchev, E., "Simulation of a Tubular Solid Oxide Fuel Cell Stack Using AspenPlus(TM) Unit Operation Models,' Energy Conversion and Management, 46(2), 181-196(2005).

12. Kuto, D., Yamamoto, O., Iwahara, H. and Yun, C. J., Fuel cell, Gyeomjisa(2007).

13. Kim, D. H. and Lee, T. J., "Kinetics of Methane Steam Reforming,' Korean J. Chem. Eng., 29(4), 396-406(1991). 